\title{
Analysis of Financial Statements as a Competitiveness Advantage of the Firms in the Greek Poultry Sector 2010-2016
}

\author{
Christos Konstantinidis*, Panagiotis Pantelidis, Nikolaos Kartzias \\ School of Business Administration, International Hellenic University, Serres, Greece \\ Email: *chkons10@gmail.com, pan@teiser.gr, kartziasn@gmail.com
}

How to cite this paper: Konstantinidis, C., Pantelidis, P., \& Kartzias, N. (2021). Analysis of Financial Statements as a Competitiveness Advantage of the Firms in the Greek Poultry Sector 2010-2016. Theoretical Economics Letters, 11, 938-946. https://doi.org/10.4236/tel.2021.115059

Received: August 17, 2021

Accepted: October 8, 2021

Published: October 11, 2021

Copyright ( 2021 by author(s) and Scientific Research Publishing Inc. This work is licensed under the Creative Commons Attribution International License (CC BY 4.0).

http://creativecommons.org/licenses/by/4.0/

\begin{abstract}
The egg industry is a sector which has a very important role in the Greek economy. The current research aimed at analyzing the financial statements of Kartzias G. SA, Tsakiris Family SA, Golden Eggs SA, Sovimo Hellas SA and Augodiatrofiki SA companies with the largest market share in the market. They belong to the food industry and they have the leading role in the market, mainly with producing and selling eggs. The analysis was conducted with the help of financial ratios, specifically Altman's Z score, on a series of 7 years, from 2010 to 2016 . With this analysis and with the help of the $Z$ score model, we can have a look at the financial image of the companies and more importantly the course they had in the big financial crisis that affected many companies in Greece. The results occurred from the analysis mentioned above show that Kartzias G. SA has significantly improved her Z score which at 2016 was at 10.061 and is in no danger of bankruptcy. Next one is Avgodiatrofiki with a $Z$ score of 1.330 at 2016 and is in the gray zone according to Altman's Z score.
\end{abstract}

\section{Keywords}

Assets, Liabilities, Net Worth, Ratios, Income, Expenses, Profit, Loss, Result, Company, Capital, Foreign Capital, Z Score

\section{Introduction}

The object of the financial analysis is the study of the assets and liabilities, their structure and the changes in the Equity. The main purpose of financial statements is to provide useful information regarding the financial position, performance, activity and cash flows of a business to various users so that they can 
make rational decisions (Lazaridis, Konteos, \& Sariannidis, 2013). Any financial or otherwise financial situation tries to reflect the behavior of the company. The information should be understood by analysts who have a basic knowledge of business as well as financial activities and are willing to deal with and examine this information in an extensive study (Kantzos, 2013). The balance sheet and the results of profit and loss of each year give us a first picture of the company regarding the most important accounting data for a company in a specific financial year. In this study, the analysis will be performed with the model of $Z$ score. The $\mathrm{z}$ score consists of some ratios, ratios are a very common tool, quite well known and used in the evaluation of a company's financial data (Benlamalih \& Nobanee, 2020; Manaseer \& Al Oshaibat, 2018). Using the Z score the analyst can examine the possibility of a possible bankruptcy of the company under analysis, in depth of 2 financial years. The more years in which the financial statements are examined using the ratios, the greater the reliability of the results. This study will have the following structure, we will first start with an analysis of the term financial statements and what it includes. There will be a presentation of the limitations and weaknesses of the Balance Sheets as well as the reasons why it is necessary to create them, then we will mention some things about the poultry industry in Greece as well as its course in the examined years based on its financial data. Then there will be a brief description of the companies we are examining with their history and other important facts. After that we present the research methodology, reference is made to the ratios used for the analysis in the $\mathrm{Z}$ score model which examines the possibility of a possible bankruptcy of the company as mentioned above and immediately afterwards the results of the analysis conducted for the financial years 2010 to 2016, years in which the economic crisis in Greece escalated. As a result, the assessment of the competitiveness of this period of economic crisis, is of particular importance, as is the study of the further course of the companies in the coming years, which will be a future work of the authors. Finally, we have the conclusions of the study which result from the elaboration and analysis of the financial data of the companies carried out in the previous section as well as the proposals for future research. Due to the fact that the poultry industry is a sector that despite its losses is showing a sign of recovery, The contribution of this research consists in the primary study of the lead companies in the egg food industry using these financial tools for the analysis of this industry which is a key part of national production in the food sector. Although we use 4 companies in the industry can be a limitation of the work, but the fact that they have the highest market share can lead to safe conclusions and policy measures for the industry, something that is of interest to both academics and politicians.

\section{Literature Review}

The studied literature which concerns the assessment of the competitiveness of a sector, with the use of financial statements varies depending on the form and 
type of the companies. The majority concern companies are listed on the stock market in which the valuation is made mainly using the following $\mathrm{Z}$ score model:

$$
Z=1.2 X_{1}+1.4 X_{2}+3.3 X_{3}+0.6 X_{4}+0.999 X_{5}
$$

It has been mentioned in the following papers:

Sina, Huda, Hossain and Sabur (2020) where they attempted to estimate a potential sickness in the garment factories in Bangladesh and they came to the conclusion that the companies need to use their assets more efficiently in order to be out of the sick zone.

In Alareeni and Branson (2012)'s study, they examined a number of 71 companies in the Jordan environment that did not bankrupt and 71 companies that did in fact bankrupt. They wanted to test whether this model of $\mathrm{Z}$ score can predict a potential bankruptcy of a company in Jordan as it was successful in predicting it in the US and EU. The result was that this variation successfully predicts (according to the data analyzed) a company's bankruptcy.

Gerantonis, Vergos and Christopoulos (2009) used it to find if it can predict business failures in Greece and found evidence that with the help of the model of $\mathrm{Z}$ score, one can predict a company's bankruptcy up to 2 years before.

BSR, Madhavi, Rajani and Maddila (2018) while using the Z score model tried to find the financial strength of Unitech Limited. The result was that the company has to focus on achieving more sales in order to have greater income and improve its $\mathrm{Z}$ score values.

Taking into account the above and because the companies examined in this study are not in the stock market, the model of $\mathrm{Z}$ score is the following:

$$
Z=0.717 * X_{1}+0.847 * X_{2}+3.107 * X_{3}+0.42 * X_{4}+0.998 * X_{5}
$$

The methodology used will be shown below in the results. This variation of $\mathrm{Z}$ score has also been mentioned in other studies such as that of Samarakoon and Hasan (2009) and Abir (2011).

\section{Financial Statements-Concept and Meaning}

Financial statements are a form of presentation of the financial data of a company such as profitability, financial position, turnover and cash flows (Lazaridis, Konteos, \& Sariannidis, 2013). The financial statements are the most reliable source for what we mentioned above, especially when audited by statutory auditors. It is important to refer to them, notes which will explain but also help users to better understand the financial picture of the business (Kantzos, 2013).

The most important financial statements are:

The Balance Sheet, which is a photo of the company that presents its financial position at a specific time. Indicates its assets, receivables and liabilities to itself and third parties (Karagiorgos, 2012).

The Profit or Loss Statement, in this statement, income and expense data are presented which resulted from the various transactions carried out by the com- 
pany, income from its sales and expenses from its purchases. The result that we take from the statement is the profit or loss that the company achieved at a specific time. Profit is the result of the business when its income is greater than its expenses and vice versa, when its expenses are greater than its income then there is loss (Karagiorgos, 2012).

The Profit Distribution Table shows how the corresponding result of the company is distributed, if it is profit it is distributed as defined by the law but also by the decision of the competent authority, while in the opposite case, if the result occurs loss, it transferred to the next use (Karagiorgos, 2012).

The Appendix of the Balance Sheet, which refers to the notes regarding the financial statements and how they are created so that each analyst can better understand them (Soumpeniotis \& Tampakoudis, 2015).

We mentioned above that the Balance Sheet is a photo of the company, presenting its financial position at a specific time, but what it shows is a result of the various transactions that took place in the past. The preparation of the Balance Sheet years ago was the main reason for the accounting process. Compared to the situation of the Profit or Loss Statement, the Balance Sheet is considered to be less important, in terms of administrative and business decisions, but it is still the main source of information (Arsenos \& Kaldis, 2008). Initially the Balance Sheet as a financial statement is quite complex. In order to be able to understand its data and make the appropriate decisions, one must have a substantial specialization in Accounting, be well acquainted with accounts management and have access to company data for more than 2 years (Lazaridis, Konteos, \& Sariannidis, 2013). The Balance Sheet does not show the current value of its data but the value of its historical cost, for example the assets of a business, are shown in the balance sheet at their acquisition value. But a country's inflation can distort the true value of a business's assets (Arsenos \& Kaldis, 2008). Also, most of the data that appear in the Balance Sheet are simple estimates as the time of collection of the debts from customers or respectively the time of repayment of liabilities to third parties cannot be accurately calculated. Finally, one of the most serious problems in the Balance Sheet is that some data is omitted because it cannot be calculated in value or size, such as the reputation of the company, its human resources, its management. Although the above are a considered a large part of the company and have a great importance, they cannot be quantified and therefore are not presented in its Balance Sheet.

\section{The Poultry Sector in Greece}

Egg production in Greece is a highly dynamic sector that, despite the fact that in the recent years it has been hit repeatedly, both by a series of food crises that occurred internationally and by the economic situation that hit companies in the country, resists and gives dynamically the battle for survival.

According to data from the Directorate of Agricultural Statistics \& Documen- 
tation of the Ministry of Rural Development \& Food, eggs produced in Greece for human consumption cover approximately $88.3 \%$ of demand nationally.

For the period 2014-2019, the average annual rate of change in sales amounted to $8.8 \%$. The presence of the sector is significant in the entire domestic industry, covering a rising share in total sales, which amounted to $1.1 \%$ in 2018.

At the same time, the share of the sector in the total sales of the food industries amounted to $5.9 \%$ in 2018 (ICAP, 2020).

The examined companies are Sovimo Hellas SA, Avgodiatrofiki SA, Kartzias G. SA, Tsakiris Family SA and Golden Eggs SA.

Sovimo Hellas SA, was founded in 1997 and is one of the largest companies active in the egg sector and cooperates with Golden Eggs SA owning 2 of the largest poultry farms in Greece. They are located in Schimatari and in Kiliomodi in Corinth. Its HQ is located in Schimatari, Boeotia. It is one of the largest companies in the egg sector with a strong presence and serves daily the entire prefecture of Attica as it has collaborations throughout the country and abroad (http://www.sovimo.gr/about-us/).

Avgodiatrofiki SA, created by the merge of the 4 largest poultry farms in Northern Greece, has units in Galatista, Halkidiki, Porto Lagos, Xanthi and Mavroneri, Kilkis. It is based in N. Santa Kilkis, where the egg collection area is located (https://avgodiatrofiki.gr/).

In 1965 in Neochorouda, an area which is famous in Greece for its eggs and chickens and is located west of Thessaloniki and about $3 \mathrm{~km}$ from Oreokastro, Kartzias G. was founded. The company is only active in egg production and sale of eggs and in 1999 it changed its form in a SA. At the same time, it closes its poultry farm in Neochorouda and moves its headquarters to Mavroneri Kilkis.

Tsakiris Family is the evolution of AVGA NEOCHOROUDA TSAKIRI and is a family business. Its headquarters are in Neochorouda and its main object of work was to produce eggs and then supply them to the market of Thessaloniki. In 1988 the second generation takes over and by the end of 1990, it had managed to expand its distribution network and serve the whole Macedonia. When the third generation decided to enter the workplace in 2005, investments were made in special farms but also in value-added products, such as organic eggs. In 2010 the form of the company becomes a Societe Anonyme (https://www.tsakirisfamily.gr/en/the-company).

Golden Eggs SA was founded in 1996 by the companies P. Skourtis SA and S. Papagiannis SA, companies that have been dealing with the production of eggs for over 5 decades. It owns over 400 acres of land in Schimatari, Boeotia, but also in Chiliomodi of Corinth, with which it exceeds 300 million eggs a year, which it produces and distributes. It is one of the first companies to change the chicken cages in 2012, as defined by the European Union. It has 40 different products with which it can cover the needs and requirements that exist in the food indus-

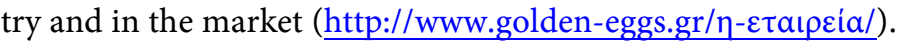




\section{Methodology}

The data we used was collected from annual balances of the companies due to the fact that the publication of balance sheet is essential for companies in Greece. This is the reason why the quality of the data is safe. The analysis was conducted with the $\mathrm{Z}$ score model which examines the possibility of the company going bankrupt. Proposed in 1968 by Dr. Edward Altman and by applying it one can predict the possible bankruptcy of a company (Gerantonis, Vergos, \& Christopoulos, 2009).

There are 3 different versions of this model. In this paper, the model we used is written as follows:

$$
Z=0.717 * X_{1}+0.847 * X_{2}+3.107 * X_{3}+0.42 * X_{4}+0.998 * X_{5}
$$

where:

$$
\begin{gathered}
X_{1}=\frac{\text { Working Capital }}{\text { Total Assets }} \\
X_{2}=\frac{\text { Retained Earnings }}{\text { Total Assets }} \\
X_{3}=\frac{\text { Earnings before Taxes and Interest }}{\text { Total Assets }} \\
X_{4}=\frac{\text { Value of Equity Capital }}{\text { Book Value of Total Liabilities }} \\
X_{5}=\frac{\text { Sales }}{\text { Total Assets }}
\end{gathered}
$$

(Takahashi, Taques, \& Basso, 2018).

The ratios are interpreted as: $X_{1}$ shows us the general liquidity of the company, when this ratio is low means that the company cannot cope with its debts, $X_{2}$ shows the ability of the company to increase its net worth over time and to self-finance, the $X_{3}$ indicates the return of capital free of interest and taxes because higher return on the capital of the company implies minimization of the risk of bankruptcy. $X_{4}$ indicates the percentage ratio between the company's equity and the total foreign capitals it uses and is therefore a strong indication of the firm's dependence on foreign capital. $X_{5}$ presents the ability of the company in terms of using its assets more efficiently resulting in an increase in overall sales.

As noted by BSR, Madhavi, Rajani, Maddila (2018), when the price of $Z$ is below the limit of 1.23 then the company is at risk of bankruptcy while if on the contrary it is above 2.90 the company is safe from risk. If prices occur that are between the 2 limits we mentioned then the company operates in an area where the possibility of bankruptcy is not certain (gray area) and in order to interpret a conclusion it is necessary to take into account other factors.

\section{Results}

Below Table 1 we see the results of the analysis. 
With the methodology we previously mentioned for companies we are examining, we observe that a considerable effort has been made to reduce liabilities and utilize assets to a greater extent in order to meet the requirements and the risk arising from the financial crisis, we observe in more detail that Kartzias G. SA since 2012 with a systematic effort to reduce its liabilities has dramatically improved the $\mathrm{Z}$ score as it is evident above in Table 1 and does not face problems from the existence of liabilities to third parties. Tsakiris Family SA along with Avgodiatrofiki SA are in the gray zone of Altman's model regarding the possibility of bankruptcy. The company Golden Eggs SA shows low values of the $Z$ ratio throughout the period under analysis, with the ratio being decreased from 2011. Similar is the trend of the ratio of Sovimo Hellas as from 2012 onwards it has been continuously falling. Tsakiris SA and Avgodiatrofiki SA show a fluctuation of the ratios in the examined period but the prices of the ratios remain at controlled levels regarding the possibility of bankruptcy. These fluctuations are clearer in Figure 1 below where we observe the correlation of the ratios between Golden Eggs SA and Sovimo Hellas as we mentioned before.

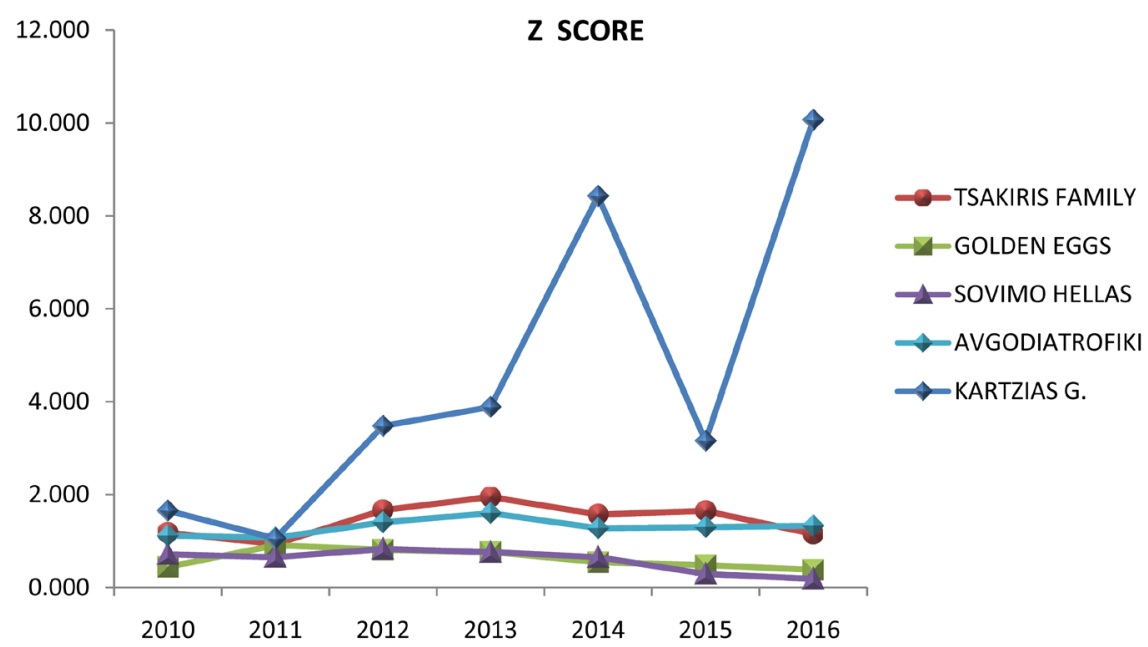

Figure 1. Z score of the lead companies in the industry, Source: Author's calculations.

Table 1. Annual Z score results for each company, Source: Author's calculations.

\begin{tabular}{lccccc}
\hline & \multicolumn{5}{c}{ Z SCORE } \\
\cline { 2 - 6 } YEAR & KARTZIAS G. & $\begin{array}{c}\text { TSAKIRIS } \\
\text { FAMILY }\end{array}$ & $\begin{array}{c}\text { GOLDEN } \\
\text { EGGS }\end{array}$ & $\begin{array}{c}\text { SOVIMO } \\
\text { HELLAS }\end{array}$ & AVGODIATROFIKI \\
\hline 2010 & 1.654 & 1.181 & 0.446 & 0.714 & 1.117 \\
2011 & 1.053 & 0.937 & 0.912 & 0.652 & 1.073 \\
2012 & 3.475 & 1.668 & 0.814 & 0.830 & 1.405 \\
2013 & 3.887 & 1.951 & 0.764 & 0.761 & 1.603 \\
2014 & 8.423 & 1.573 & 0.544 & 0.650 & 1.277 \\
2015 & 3.156 & 1.650 & 0.485 & 0.294 & 1.303 \\
2016 & 10.061 & 1.154 & 0.382 & 0.187 & 1.330 \\
\hline
\end{tabular}




\section{Conclusion}

The Z-score model is a very practical tool that can be used to predict the bankruptcy of companies as well as their financial course over time. Many other factors may have affected the company's performance, factors that cannot be quantified, such as staff morale, reputation of the company, its human resources, its management, etc. In this paper, a small but important sample of the egg food industry was analyzed (perhaps this is a limitation of the research as well). During the economic crisis there was an attempt by the companies to reduce their liabilities and improve their prospects. However, the fact that the companies are one of the largest companies in the Greek egg sector can help us reach safer results. The $\mathrm{Z}$ score model as an analysis tool should be combined with other methods of analyzing financial statements to get more accurate results about the viability and further development of the companies and their work sector and compare these results with the sector as a whole. Therefore, it is particularly important for the state to support companies in the sector by taking measures that will stimulate competitiveness and improve their strategy, such as facilitating extroversion, reducing tax rates, tackling bureaucratic problems and easier export orientation.

\section{Conflicts of Interest}

The authors declare no conflicts of interest regarding the publication of this paper.

\section{References}

Abir, Md. Z. T. (2011). ALTMAN’S Z-Score Analysis: ACI Limited (pp. 2-3). https://www.academia.edu/2408674/ALTMAN_S_Z_Score_Analysis_ACI_Limited?sm $=\mathrm{b}$

Alareeni, B., \& Branson, J. (2012). Predicting Listed Companies' Failure in Jordan Using Altman Models: A Case Study. International Journal of Business and Management, 8 , 113-126. https://doi.org/10.5539/ijbm.v8n1p113

Arsenos, P., \& Kaldis, P. (2008) .Applied Business Finance. Publications Pataki.

Benlamalih, A., \& Nobanee, H. (2020). Financial Analysis of McDonald's (p. 1). Research Gate.

https://www.researchgate.net/publication/342702949_Financial_Analysis_of_McDonal d's

BSR, M., Madhavi, N., Rajani, N., \& Maddila, G. (2018). Financial Strength Analysis of Unitech Company Using Altman's Z Score Model. International Research Journal of Engineering and Technology (IRJET), 5, 1805-1809.

https://www.academia.edu/36866854/Financial_Strength_Analysis_of_Unitech_Comp any_Using_Altman_s_Z_score_Model?sm=b

Gerantonis, N., Vergos, K., \& Christopoulos, A. (2009). Can Altman Z-Score Models Predict Business Failures in Greece? Research Journal of International Studies, 12, 21. https://www.academia.edu/338693/Can_Altman_Z_Score_Models_Predict_Business_F ailures_In_Greece 
ICAP, Economic Research ICAP in the Poultry Sector (2020).

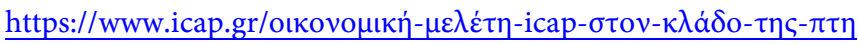

Kantzos, K. (2013). Analysis of Financial Statements. Publications FEDIMOS.

Karagiorgos, Th. (2012). Introduction to Financial Accounting. TH. KARAGIORGOS BROS OE.

Lazaridis, Th., Konteos, G., \& Sariannidis, N. (2013). Modern Financial Analysis.

Manaseer, S., \& Al Oshaibat, S. (2018). Validity of Altman Z-Score Model to Predict Financial Failure: Evidence from Jordan. International Journal of Economics and Finance, 10, 181-189. https://doi.org/10.5539/ijef.v10n8p181

Samarakoon, L., \& Hasan, T. (2009). Altman's Z-Score Models of Predicting Corporate Distress: Evidence from the Emerging Sri Lankan Stock Market. Journal of the Academy of Finance, 119-125.

https://www.researchgate.net/publication/228299415_Altman\%27s_Z-Score_Models_o f_Predicting_Corporate_Distress_Evidence_from_the_Emerging_Sri_Lankan_Stock_ Market

Sina, M., Huda, M., Hossain, H., \& Sabur, M. (2020). Identification of Sickness of Some Selected Garment Factories in Bangladesh and Its Remedial Measures: An Application of Altman's Z-Score Model. American Journal of Industrial and Business Management, 10, 1823-1838. https://doi.org/10.4236/ajibm.2020.1012113

Soumpeniotis, D., \& Tampakoudis, I. (2015). Financial Analysis. Soumpenios Dimitrios, Tampakoudis Ioannis.

Takahashi, M., Taques, F., \& Basso, L. (2018). Altman's Bankruptcy Prediction Model: Test on a Wide Out of Business Private Companies Sample. iBusiness, 10, 21-39. https://doi.org/10.4236/ib.2018.101002 